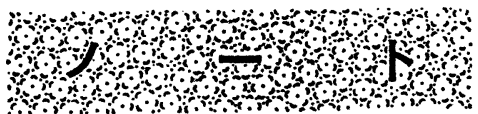

\title{
ポリアミドを用いた食品中の合成着色料の迅速分析
}

(昭和 61 年 12 月 16 日受理)

\author{
角田光淳* 井上典子* \\ 青山光 雄* 長谷部昭久*
}

\section{Rapid Analysis of the Food Colors in Foodstuffs Using Polyamide}

\author{
Kojun Tsunoda, Noriko Inoue, Mitsuo Aoyama \\ and Akihisa HASEBE
}

(Suginami Ward Institute of Public Health Research, Tokyo: 3-20-3, Takaidohigashi, Suginami-ku, Tokyo, Japan)

\begin{abstract}
A rapid and simple analysis procedure involving a batch system using polyamide (nylon-6 powder) was devised for the detection of food colors. The food colors were extracted from food with a mixture of $1 \%$ ammonia water and ethanol $(4: 6)$. The extract was filtered, and the filtrate was diluted two or three times with water. The colors in the solution were absorbed on a small amount of polyamide $(10-30 \mathrm{mg})$ in acid $(\mathrm{pH} 4-5)$. After filtration and rinsing with hot water, the polyamide was suspended and eluted with a small quantity (about $100 \mu 1$ ) of a mixture of $28 \%$ ammonia water and ethanol (4:6). After five min, the supernatant was used for paper chromatography and thin layer chromatography on a silica gel plate or a polyamide sheet. The solvent systems for the chromatographies were as follows: paper chromatography, butanol-ethanol-1\% ammonia water (6:2:3); silica gell thin layer chromatography, ethyl acetate-ethanol-28\% ammonia water $(3.3: 1: 1)$ or $(4.5: 1: 0.7)$; polyamide thin layer chromatography, methanol-ethanol-isoamyl alcohol-28\% ammonia water $(15: 10: 5: 3)$. The systems containing ammonia as described above were required for separation of the food colors. Compared with the wool dyeing method, the presented method did not require evaporation of alcohol, heating for adsorption or elution of the food colors or concentration of the eluate. It is rapid, simple and precise for the detection of the food colors in various colored foods.
\end{abstract}

(Received December 16, 1986)

Key words: 食用色素 food colors; ポリアミド polyamide; ナイロン-6 末 nylon-6 powder; 薄 層クロマトグラフィー thin layer chromatography; ろ紙クロマトグラフィー paper chromatography; 毛糸染色法 wool dyeing method

\section{緒言}

着色食品中に含まれる合成着色料1る分離する方法と

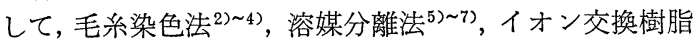

\footnotetext{
* 東京都杉並区衛生試験所：東京都杉並区高井戸東 3-20-3
}

法5),8) 15)，カラムクロマトグラフィー16) 19) 及びポリア ミドを用いた方法20) 22) などの報告がなされ，紹介 ${ }^{23)}$ れている. このうち毛系染色法は, アルコールの揮散, 色素の染着及び溶出時の加温操作などが必要にもかかわ らず，粘着性のある食品, 乳化剤を含む食品などにも広 
く適用でき，染着毛糸の洗浄の容易さなどの簡便性から 広く一般的に用いられている，ポリアミドを用いる方法 は，本品が羊毛と同じポリアミド構造 ${ }^{24)}$ を持つことに着 眼したもので，その性質は Lehmann et. al. ${ }^{20)} \mathrm{Da}$. videk et. al., ${ }^{21), 22)}$ の報告の中にもあるように, 迅速な 吸着能と吸着した色素の溶離性に優れた利点を持ってい る.しかし，いずれのポリアミド染色法も，アルコール の揮散やカラム操作として吸着した色素の溶出，その溶 出液の濃縮などの操作性において, 毛系染色法の優位性 を認めざるを得ない。しかし，著者らはポリアミドの利 点に着目し, 我が国で許可されている食用色素11種につ いて，ポリアミド (ナイロン-6末)を用いて毛䒺染色法 に代わる簡易な迅速分析法を検討した。

\section{実験方法}

\section{1. 試料, 試薬及び装置}

\section{1 試料}

試料は, 着色市販食品 506 検体 (和・洋菓子 254 検体, 清涼飲料水 38 検体, 乳 - 肉加工品 7 検体, 魚介類加工品 21検体，漬物79検体，そう菜18検体，その他89検体）を 用いた。

1.2 試薬

ポリアミド：ポリ (6-ヘキサンアミド) ナイロン-6 末・薄層クロマトグラフィー (TLC) 用ポリアミド B-O

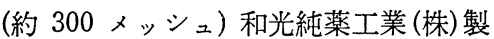

標準合成着色料：食用赤色 2 号 (R-2), 同 3 号 (R-3), 同 102 号 (R-102), 同 106 号 (R-106), 食用黄食 4 号 (Y$4)$, 同 5 号 (Y-5), 食用青色 1 号 (B-1), 同 2 号 (B-2) 三 栄化学工業 (株) 製. 食用赤色 104 号 (R-104), 同 105 号 (R-105), 食用緑色 3 号 (G-3) 国立衛生試験所標準品

合成着色料：食用許可色素（11種類）東京 化成工 業 (株) 製

溶離液 I：1\%アンモニア水-エタノール $(4: 6)$ 混液

溶離液 II：濃アンモニア水ーエタノール $(4: 6)$ 混液

染着液： $\mathrm{pH} 5.0,0.02 N$ 酢酸アンモ二ウム緩衝液ーエ タノール $(10: 0),(7: 3),(4: 6)$ 混液

展開溶媒：(1) n-ブタノール-エタノール $-1 \%$ アンモ 二ア水 $(6: 2: 3)$, (2) 酢酸エチルーメタノール $-28 \%$ アンモ

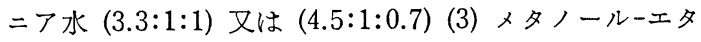
ノールーイソアミルアルコール $-28 \%$ アンモニア水 $(15:$ 10:5:3) いずれも用時調製した.

その他の試薬は，すべて特級試薬を使用した。

1.3 装置, 器具

クロマトグラフィー用ろ紙：東洋濾紙 No. 50

TLC 用シリカゲルプレート: DC-Fertigplatten Kieselgell 60 メルク社製

TLC 用ポリアミドシート：ポリアミドレイヤーシー

ト Cheng Chin Co. Ltd. 製 (和光純薬工業(株)販売)

\section{2. 試験溶液の調製}

2.1 試料からの色素の溶出
（1）液体試料は約 $10 \mathrm{ml}$ を採り，そのままろ紙で ろ過し, 着色ろ液を試料液とした。

（2）個体試料は約 $10 \mathrm{~g}$ を細断し，3〜5 倍量の溶離 液 I を加えて，1 夜放置又はホモジナイズして，色素を 溶出させた。これをろ過したろ液を，水で $2 \sim 3$ 倍に希 釈して試料液とした。

\section{2 ポリアミドによる試料液の精製}

試料液に, ポリアミドを少量 $(10 \sim 30 \mathrm{mg})$ 加え, 酢酸 で $\mathrm{pH}$ 4〜 5 に調整して時々攪はんしながら，10 分間放 置した.それをろ紙でろ過し，着色したポリアミドを温 湯で洗い小試験管にかき取った，油脂を多く含む食品 で，ろ過したポリアミドがべたついているよらな場合 は，エタノール又はェーテルで洗浄した。 小試験管に溶 離液 II を少量 $(100 \sim 200 \mu 1)$ 加えて, 5 分間放置しその 上澄液をろ紙クロマトグラフィー（PC）及び TLC 用 試験溶液とした。

\section{PC 及び TLC による分離同定}

ろ紙, シリカゲルプレート又はポリアミドレイヤーシ 一ト上に, 試験溶液をスポットし風乾した後，PCは展開 溶媒 (1), シリカゲル TLCは (2), ポリアミド TLCは （3）で標準品と同時に展開し，分離同定した.

\section{4. ポリアミド及び毛糸の食用色素に対する吸着}

食用色素11種類を，それぞれ染着液 $(10: 0),(7: 3)$ 及び (4:6) に溶かし， 0.5\% 色素溶液を調製した. ポリアミド 区分にはポリアミド $0.5 \mathrm{~g}$, 毛系区分には脱脂白色毛系 $0.5 \mathrm{~g}$ を, 各色素溶液 $100 \mathrm{ml}$ に加え, 時々攪はんしなが ら 30 分間放置し色素を染着させた後, 染着液 $20 \mathrm{ml}$ 3 回洗浄した.ポリアミド区分は溶離液 I を $20 \mathrm{ml}$ 加え て靦はんし，30分間放置後遠心分離した．この操作を 3 回繰り返し，得られた上澄液を合せた後，酢酸で中和し て試験溶液とした. 毛系区分は $1 \%$ アンモニア水 $20 \mathrm{ml}$ で30分間水浴中で加温し溶出させた。 この操作を 3 回繰 り返し，その溶出液を合せて酢酸で中和し，試験溶液と した，それぞれの吸光度を求め，この值及びあらかじめ 作製した各検量線より吸着量を求めた.

\section{5. 染着液中における色素の吸着}

11種の色素を用い，それぞれ染着液で色素溶液 100 $\mathrm{ml}$ にポリアミド $1 \mathrm{mg}$ を加え色素を染着させた. そし て $0.5,2,5,10,20,40$ 分ごとにその染着懸濁液 $10 \mathrm{ml}$ を素早く注射筒に採り，メンブランフィルターでろ過 し，直ちに染着液で洗浄したフフィルタ一中の染着ポリ アミドを採り, 溶離液 I を $10 \mathrm{ml}$ 加えて, 攪はんし，30 分間放置後遠心分離して溶出させた.この操作を 3 回繰 り返し，その溶出液を合せて，酢酸で中和して吸光度を 求め, 前記と同様に吸着量を求めた.

\section{結果及び考察}

合成ポリアミドであるナイロンは，天然ポリアミドの 羊毛と同じく，酸性条件下で $\mathrm{N}$-末端基に酸性色素が結 合するが，ナイロンは羊毛に比べてその染着座は $1 / 20$ 
Table 1. Rate of Color Adsorption on Polyamide (Nylon Powder) and Wool

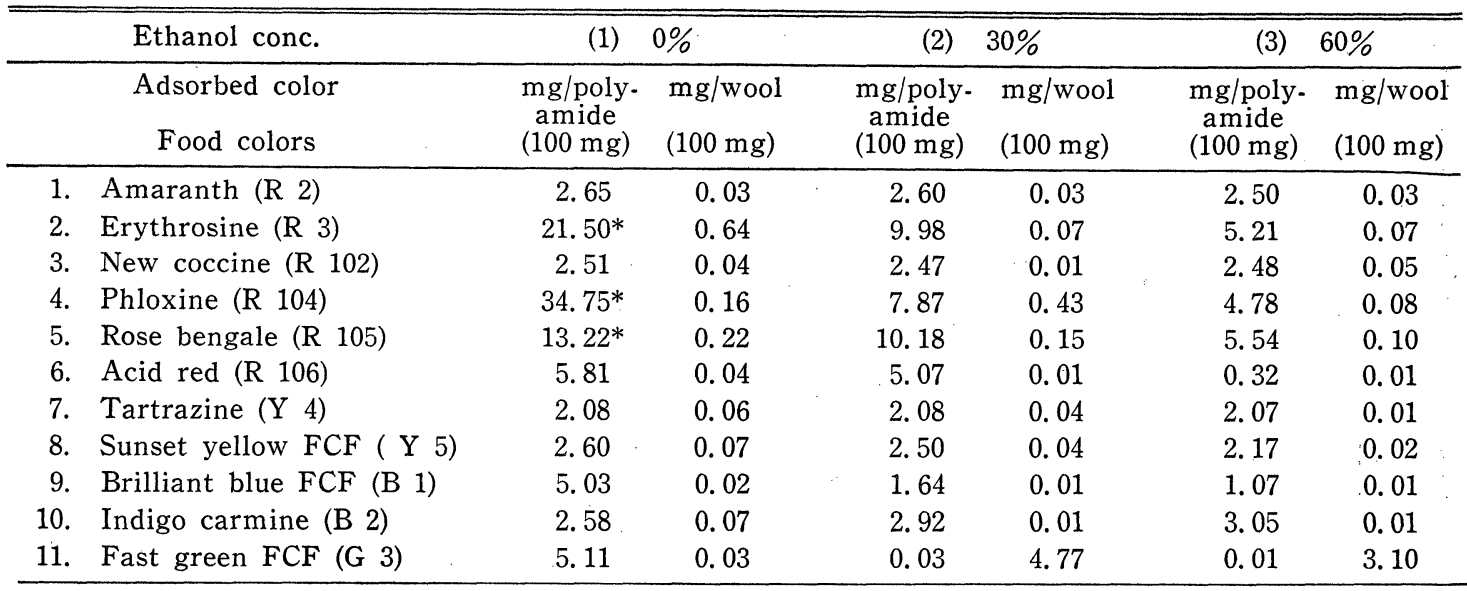

*: Contain the precipitated color

(1) $0 \%: \mathrm{pH} 5.0,0.02 \mathrm{~N}$ acetate buffer (2) $30 \%: \mathrm{pH} 5.0,0.02 \mathrm{~N}$ acetate buffer-ethanol $(7: 3)$

(3) $60 \%: \mathrm{pH} 5.0,0.02 \mathrm{~N}$ acetate buffer-ethanol (4:6)

程度と言われている25)。 また，重合度が高いほど N-末 端基が少なく染着座は少ない26). 羊毛の構成成分は $\alpha$ アミノ酸で, ナイロン-6は 8 -アミノカプロン酸であり, 構成単位の炭素数が異なり，ポリマーの極性が異なる. つまりナイロンは毛系に比べて疎水性の比較的高い色素 をよく吸着する27).

\section{1. ポリアミド及び毛糸の食用色素に対する吸着}

ポリアミドの吸着能は毛糸に比較して, いずれの色素 も常温下でエタノールの有無を問わず食用色素をよく吸 着した. その結果を Table 1 に示した.

\section{2. ポリアミド及び毛糸に染着した食用色素の溶離}

実験方法 4 に準じ, 染着液 (7:3) で染着させたポリア ミド（ポリアミドとして $100 \mathrm{mg}$ ) と毛糸（毛糸として $100 \mathrm{mg}$ ) について, 溶離液 I の $20 \mathrm{ml}$ の溶離能を試験 した. $1 \%$ アンモニア水での常温下30分間放置による毛 系からの溶出率は, 毛糸染色法の溶出条件 (1\% アンモ ニア水を用いて, 水浴中で30分間加温) と比較して, B2 を除く 10 種の平均で約 $9.0 \%$ であった. また, 溶離 液 I では，同じく 10 種の平均で $6.5 \%$ であった.

一方, ポリアミドは, 溶離液 I で, 常温 5 分間放置に より, 11種の着色料について, 全溶出量の $95 \%$ 以上を 溶出した.

\section{3. ポリアミドの食用色素に対する吸着条件の検討}

\section{$3.160 \%$ エタノールに护ける $\mathrm{pH}$ の影響}

4.2, 4.3 の実験結果から，60\% エタノール中に拉け るポリアミドの吸着性について $\mathrm{pH}$ を変えて試験した. その結果を Fig. 1 に示した. いずれの色素も, $\mathrm{pH} 7.0$ から 4.0 に低下するに従い, 吸着率は溸次増加の傾向を 示した. 一方, R-106 が非常に吸着しにくいことが分か った. $\mathrm{pH}$ から見た効率的な吸着範囲は $\mathrm{pH} 4.0$ ～5.0 で

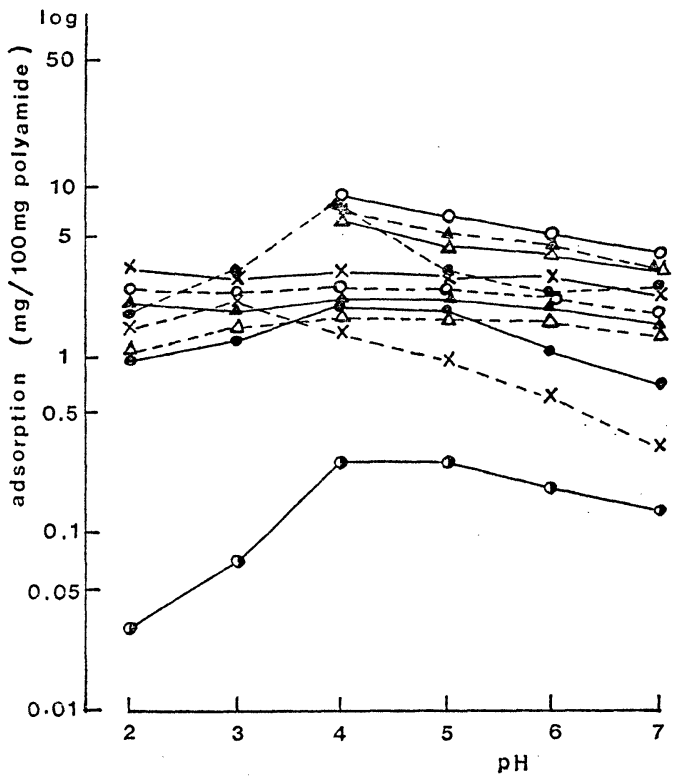

Fig. 1. Effect of $\mathrm{pH}$ of $60 \%$ ethanol solution on adsorption

color solutions: color $0.25 \mathrm{~g} / 100 \mathrm{ml}$ of $0.02 \mathrm{~N}$ ammonium acetate buffer adjust to $\mathrm{pH} 7.0 \sim 4.0$ with acetic acid and $\mathrm{pH}$ $3.0 \sim 2.0$ with hydrocloric acid adsorption: to $1 \mathrm{~g}$ of polyamide, stand. ing for $30 \mathrm{~min}$. with occasional stirring at room temperature

O—O: R3; $\Delta$-... : R105; $\triangle-\Delta$ : R104;

-...: G3; $\quad x-x$ : B2; O...O: R2;

$\Delta-\Delta:$ R102; $\triangle \cdots \Delta:$ Y 4 ; $\bullet-\bullet: \quad Y 5$; 


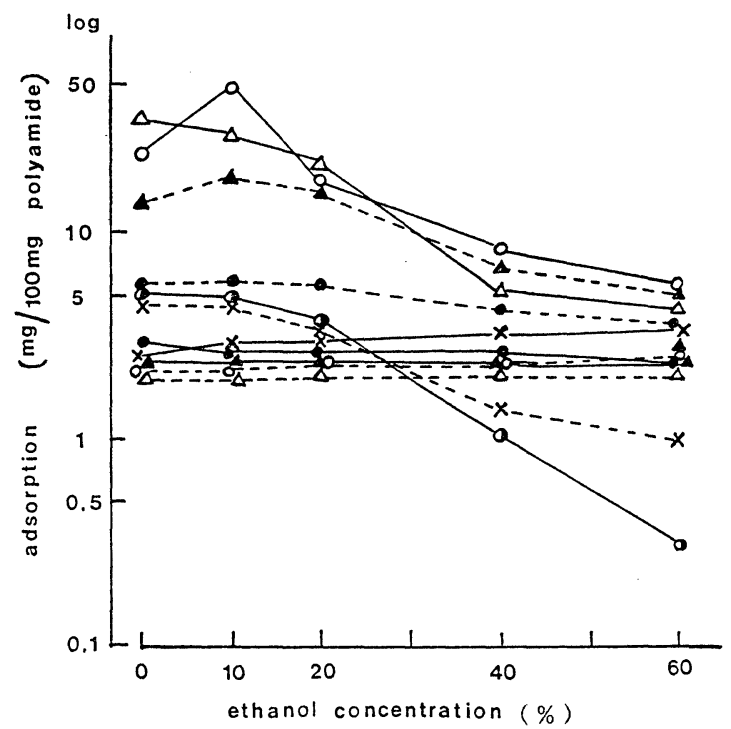

Fig. 2. Effect of ethanol concentration on adsorption at $\mathrm{pH} 5.0$ color solutions: color $0.25 \mathrm{~g} / 100 \mathrm{ml}$ of $(0 \sim 60 \%)$ ethanol with $\mathrm{pH} 5.0,0.02 \mathrm{~N}$ am. monium acetate buffer solution adsorption: same as Fig. 1 marks: same as Fig. 1

あった。

\section{2 エタノール濃度の影響}

上記の効率的な $\mathrm{pH} 4.0$ ～5.0 飞执いても吸着しにく かった R-106, B-1 について, エタノール濃度を下げ, 溶媒極性を上げて吸着能力を試験した. $\mathrm{pH}$ は 5.0 亿調 整した。 その結果を Fig. 2 に示した. エタノール濃度 の低下により両性電解質の R-106, B-1, G-3 に対する 吸着性が増加することが示された， R-106, B-1 の吸着 性を，アゾ系色素程度に向上させるためには，エタノー 几濃度を 1/2 1/3 に希釈すればよいことが分かった。

3.3 染着液 $(7: 3)$ 中に批忊る吸着率

ポリアミドの $0.25 \%$ 色素溶液中に扣沙る吸着率につ いて, 経時的に試験した. その結果はいずれの色素も 2 分で $90 \%$ 以上を吸着し，10分程度で平衡状態に達し吸 着はほぼ終了した。

\section{4. 染着ポリアミドからの食用色素の溶出条件}

キサンテン系色素は染着性がよく, これらが薄く着色 したタンパク性食品や毛糸から，色素を溶出させること は難しい，そこで, 特に溶出の困難な R-3 を実験方法 4 に準じ染着液 (7:3) で染着させたポリアミドを用いて検 討した.

4.1 アンモニア水による溶出について

R-3 染着ポリアミド (erythrosine $9.8 \mathrm{mg} / 100 \mathrm{mg}$ of polyamide) に，0〜28\% のアンモニア水を加光てその

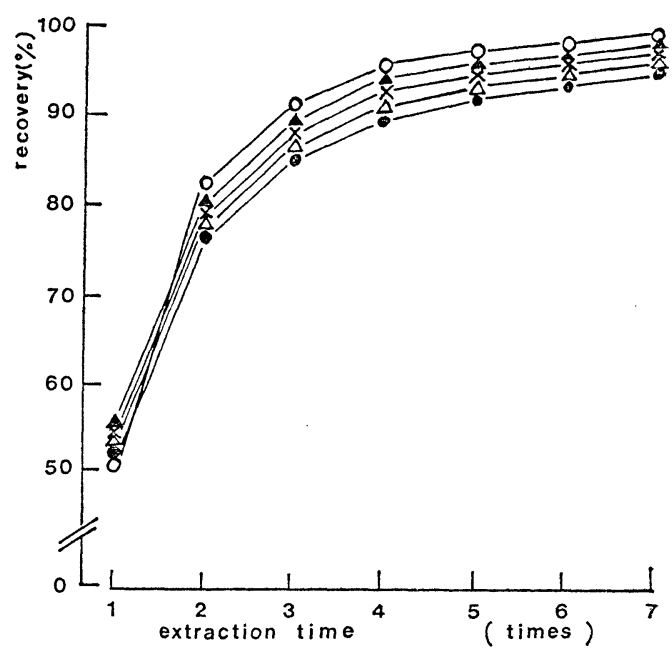

Fig. 3. Effect of ammonia concentration on elution of Erythrosine from the polyamide

adsorbed polyamide: erythrosine 9.8 $\mathrm{mg} / 100 \mathrm{mg}$ of polyamine

eluent: $20 \mathrm{ml}$ of ammonia water $/ 100 \mathrm{mg}$ of polyamide

elution: stand for $30 \mathrm{~min}$. with occasional stirring at room temperatur ○-○: ammonia concentration $28 \%$

$\Delta-\boldsymbol{\Delta}$ : ammonia concentration $10 \%$ $\times-\times$ : ammonia concentration $5 \%$ $\triangle-\triangle$ : ammonia concentration $3 \%$ - - : ammonia concentration $1 \%$

溶出効果を試験した．その結果を Fig. 3 に示した. ア ンモニア水による溶出率は 1 回につき $50 \%$ 程度であり, 半隇する溶出線が示された. 平衡に達するまで10回程の 抽出が必要で, 強い染着性が示された. 強く染着した色 素の溶出には溶出溶媒が多い程, 又はアンモニア水が濃 い程有利であることが示嘫された。

\section{2 エタノールの溶出効果}

キサンテン系色素はシリカゲル TLC ${ }^{15), 28), 29)}$ に打い て，極性の低い展開溶媒を用いたとき大きな $\mathrm{R} f$ 值を与 え, 疎水性が高いことを示している。 そこで，エタノー ルによる溶出効果を試験した結果, Fig. 4 のようにエタ ノール濃度 50 ～60\% に执いて最大の効果を示した.

\section{3 溶離液 I による溶出率}

各色素の染着ポリアミドについて, 溶離液 I $20 \mathrm{ml}$ に よる溶出試験を行った．結果はいずれの色素も5 分間放 置により $95 \%$ 以上が溶出された. 親水性の高いアゾ系 色素の溶出率は低めであった。

4.4 強く染着した微量のキサンテン系色素の溶出 毛系染色法に打ける微量のキサンテン系色素は染着毛 


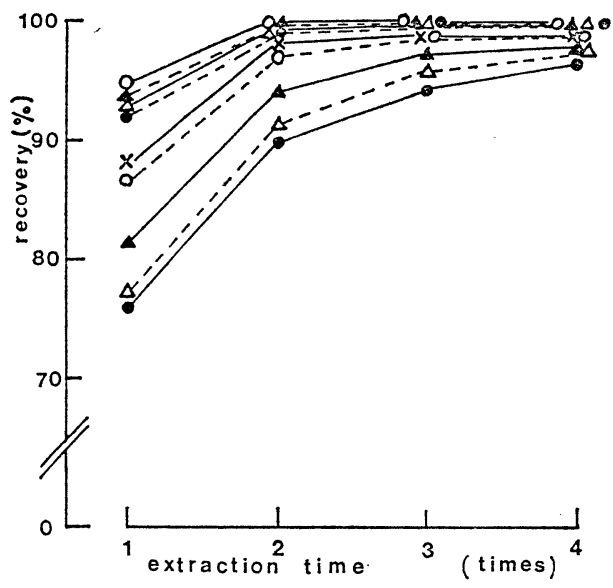

Fig. 4. Effect of ethanol concentration on elu. tion of Erythrosine from the polyamide adsorbed polyamide: same as Fig. 4 eluent: $20 \mathrm{ml}$ of $(10 \sim 90 \%)$ ethanol with $1 \%$ ammonia water elution: same as Fig. 3

$\bigcirc-\bigcirc$ : ethanol concentration $60 \%$

A-.... : ethanol concentration $50 \%$

$\triangle-\triangle$ : ethanol concentration $70 \%$

-...: ethanol concentration $40 \%$

$x-\times$ : ethanol concentration $30 \%$

○...०: ethanol concentration $28 \%$

A-A: ethanol concentration $20 \%$

$\triangle \cdots \Delta$ : ethanol concentration $90 \%$

- - ethanol concentration $10 \%$

系から溶出し難く分析が困難である、ポリアミドについ ても同様に溶出し難い，そこで，実験方法 4 亿準じて, 染着液 $(7: 3)$ でポリアミド $100 \mathrm{mg} に 11$ 種類の許可色 素をそれぞれに染着させた．それに約 1，3，5，10，28\% 溶離液 $10 \mathrm{ml}$ を加えて, 5 分間放置し遠心分離した. こ の操作を 4 回繰り返して, 十分に色素を溶出させポリア ミドの脱色度を肉眼観察した.

その結果, アゾ, トリフェニルメタン, インジゴイド 及び 両性電解質の色素は $3 \%$ 以上のアンモニア濃度で よく溶出した。 キサンテン系色素は Fig. 3 で示された ようにアンモニア濃度が高い程溶出効果も高かった．溶 離液 II が食品や色素の種類を選ぶことなく, 最も確実 に溶出された。

4.5 アルカリ性下に淤ける B-2 の安定性

B-2 はアルカリに不安定である. そこで, 毛系染色法 で行らアンモニアアルカリ性溶出時の熱処理と, 食品か らの色素の溶出に用いる溶離液 I 及 び本分析法の試験 溶液の調製に用いる溶離液 II 中に抢ける B-2 の安定性 について試験した. その結果を Fig. 5 に示した. 毛系 染色法の溶出条件では，B-2 は汪とんど退色した。溶離

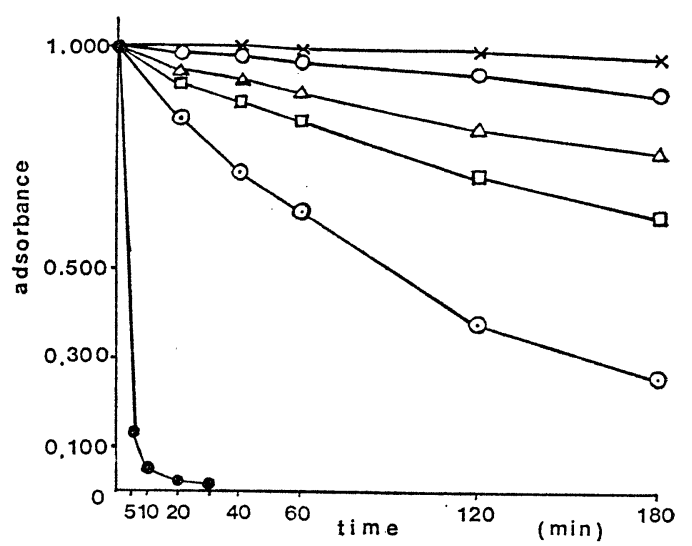

Fig. 5. Change of time corse of Indigo Carmine (B-2) in ammonia ethanol mixture condition: $20 \mathrm{ppm}$ solution of B.2 in $60 \%$ ethanol with ammonia water at room temperature
$x-x: 1 \%$ ammonia ethanol
○-०: $3 \%$ ammonia ethanol
$\triangle-\triangle: \quad 5 \%$ ammonia ethanol
$\square-\square: 10 \%$ ammonia ethanol
○-○: $28 \%$ ammonia ethanol
- $1 \%$ ammonia water in water bath $\left(100^{\circ} \mathrm{C}\right)$

液 I 中での退色はわずかで，室温で 24 時間放置した ときの退色率は $10 \%$ 程度であった。 また, 溶離液 II 中 の退色率は，室温，3時間で約 75\% であった。

\section{5. クロマトグラフィー}

PC 及び TLC による分離同定

簡易迅速性の点から言えば, ポリアミド $\mathrm{TLC}^{15), 30), 31>}$ は染着ポリアミドに少量の水を加えた懸濁液をスポッ 卜乙展開すればょいが，さらに他の TLC P PC にひ 広く適用できるように検討した. その結果, 染着ポリア ミドに溶離液 II を少量 $(100 \sim 200 \mu 1)$ 加え, 約 5 分間静 置し，直ちにその上澄液を直接スポットした，展開溶媒 は，アンモニアを含むアルカリ性のものが良く, 1.2 で 前述の組成などが良好に展開分離した.

\section{6. 市販食品への適用}

本分析法を和・洋菓子, 清涼飲料水, 乳・肉・魚介類 加工品, 漬物, そう菜などの食品 506 検体に用いたとこ ろ, PC p TLC に上る色素の分離同定に㧤いて, 食品 成分の妨害によるテーリングや $\mathrm{R} f$ の変動も全くと言っ ていいほど見られず, 標準品の $\mathrm{R} f$ 值と非常によく一致 し, 毛系染色法では不能な B-2 やキサンテン系色素の 微量分析にも十分であった。 その結果を Table 2 に示 した.

\section{まとめ}

得られた本分析法を毛系染色法と比較すると次のと括 
Table 2. Food Colors in Commercial Foods

\begin{tabular}{|c|c|c|c|c|c|c|c|c|c|c|c|c|}
\hline Sample & $\begin{array}{l}\text { No. of } \\
\text { sample }\end{array}$ & $\mathrm{R}-2$ & $\mathrm{R}-3$ & R-102 & R-104 & R.105 & R-106 & Y -4 & Y.5 & B.1 & B.2 & G-3 \\
\hline Confectioneries & $254(121)$ & 3 & 51 & 15 & 3 & 2 & 11 & 50 & 16 & 31 & 2 & \\
\hline Soft drinks & $38(16)$ & & & 3 & & & & 13 & 5 & 9 & & \\
\hline Dairy, meat products & $7(2)$ & & & 1 & & & & 1 & 1 & 1 & & \\
\hline Marine products & $21(11)$ & & 2 & 6 & & & 4 & 4 & 6 & 1 & & \\
\hline Pickles & 79 ( 19$)$ & & 1 & 5 & & & 8 & 9 & 3 & 9 & & \\
\hline Daily dishes & $18(4)$ & & & & & & & 4 & 4 & & & \\
\hline Others & $89(14)$ & & 2 & 2 & & & 4 & 7 & 1 & 7 & & \\
\hline
\end{tabular}

( ) No. of sample detected

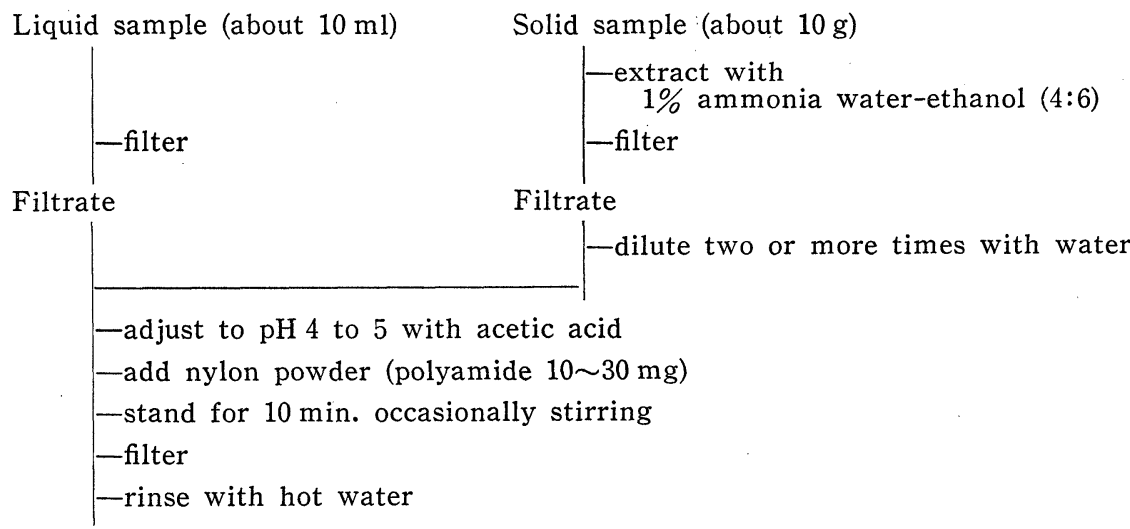

Polyamide

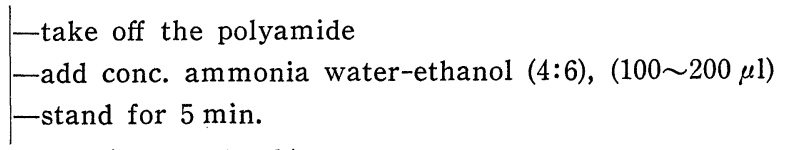

Supernatant (prepared sol.)

TLC, PC

Scheme 1. Analytical procedure for food color in food

りである.

1. ポリアミドは不純物が少なく, 毛杀のように脱脂, アルカリ処理が不要であった. 2. 試料溶液中のアルコ ールの揮散処理が 不要であった. 3. 吸着速度が速いた め, 30 分間加温する事なく, 常温下 10 分間放置で十分吸 着した．4．溶離特性が良いため，30分間加温する事な く，常温下 5 分間放置で十分溶離した． 5. ポリアミドの 色素吸着能が良いため得られた試験溶液中の色素濃度が 高く, 中和濃縮操作が不要であった. 6. 毛糸染色法で施 される熱アルカリ処理において，注とんど消失してしま 5 B-2 分析にも十分対応できた. 7. 吸着及び溶離特性 がよいため，毛系染色法では著しく困難なキサンテン系 色素の微量分析が可能であった. 8. 市販食品 506 検体 に適用したところ，全く不都合がなく非常にまとまりの 良い安定したクロマトグラムが得られた。このように， 本分析法による食用許可色素11種類の分析はこれまでに
なく, 簡易で効率良く, 精度, 迅速性にも優れたもので あった。

なお，本研究の要旨は，日本食品衛生学会第51回学術 講演会 (1986年 5 月 東京) に和いて発表した.

稿を終わるにあたり，標準色素を提供して戴いた東京 都立衛生研究所広門雅子氏及び三栄化学工業(株), そし て貴重な文献を戴いた東京都立繊維試験所大久保愛二氏 に深謝いたします。

文献

1）食品添加物公定書注解編集委員会編：第三版食品 添加物公定書注解 p. 419 494 (1974) 金原出版, 東京.

2) Association of Official Agricaltural Chemists: Association of Official Methods of Analysis, 7th, Ed. p. 652 653 (1950) Washington, D. C.

3）日本薬学会編：“衛生試験法・注解” p. 351 374 
(1980) 金原出版，東京。

4) 山本勝彦, 森山繁隆, 坂部美雄: 食衛誌, 13,22 $\sim 28$ (1972).

5) Trace Materials (Colours) Committee of the British Food Manufacturing Industries Research Association, 1st Report: Analyst 88, 864 871 (1963).

6) Sohar, J.: Z. Lebensm. Unters. Forsch. 132, 359 362 (1967).

7) Perdich, A., Prihavec, D.: ibid. 134, 239 242 (1967).

8) Dolinsky, M., Slein, C.: Anal. Chem. 34, 127〜129 (1962).

9) 藤田幸江, 志村 博: 日化. 88, 70 73 (1967).

10) 外海泰秀: 衛生化学 19, 231 235 (1973).

11) Graichen, C., Moliton, J. C.: J. Assoc. Off. Anal. Chem. 46, 1022 1029 (1963).

12) Graichen, C.: ibid. 58, 278 282 (1975).

13) 西島基弘, 上村 尚, 冠 政光, 高橋尚子, 中里 光男, 渡辺優子, 木村康夫, 直井家寿太: 食衛 誌. 18, 463 469 (1977).

14) 大井尚文, 稲葉栄司: 薬誌. 87, 741 743 (1967).

15) 竹下隆三, 坂上米次: 衛生化学 15, 72 76 (1969).

16) Yanuka, Y., Shalon, Y., Weissenberg, E., Nir-Grosfeli, I.: Analyst 88, 872 876 (1963).

17）能勢憲英：食衛誌。 11，46～48 (1970).
18) Graichen, C., Sclar, R. N., Ettelstein, N., Freeman, K. A.: J. Assoc. Off. Agri. Chem. 38, 792 796 (1955).

19）丸山幸三，川鍋康晴：食衛誌. 15，226～231 (1974).

20) Lehmann, G., Hahn, H.: Z. Analyst. Chem. 238, 445 456 (1968).

21) Davidek, J., Davidková, E.: Z. Lebensm. Unters. Forsch. 131, 99 101 (1966).

22) Davidek, J.: ibid. 132, 285 291 (1967).

23）神蔵美枝子：食品衛生研究 20, 817～826 (1970).

24）繊維学会編：“繊維便覧（原料編” p. 583～611 (1978) 丸善 (株), 東京.

25）繊維学会編：“繊維便覧（加工編）” p. 810 819, 772 791 (1978) 丸善 (株), 東京.

26) 高沢弘明, 片山 明, 黒木宣彦: Sen-i Gakkaishi 35, 54 60 (1979).

27）日本学術振興界染色加工第 120 委員会編：“新染 色加工講座一4 染色・堅ろ弓性の理論” p. 168 174 (1972) 共立出版 (株), 東京.

28）神蔵美枝子：食衛誌. 7, 338～342 (1966).

29) 藤井清次, 神蔵美枝子：化学の領 域 増刊号 64, 173 184 (1964).

30) Takeshita, R., Yamashita, T., Itoh, N.: J. Chromatogr. 73, 173 183 (1972).

31) 竹下隆三: 衛生化学 16, 293〜306 (1970). 